\title{
TAMAN TEMATIK EDUKASI 5R SEBAGAI STRATEGI PEMANFAATAN LIMBAH SAMPAH ORGANIK DAN ANORGANIK
}

\author{
Tjokorda Istri Praganingrum(1), Ida Bagus Suryatmaja'), I Gusti Agung Gede Eka Martiningsih ${ }^{3)}$ \\ 1)Universitas Mahasaras wati Denpasar \\ email: praganingrum@unmas.ac.id \\ 2)Universitas Mahasaras wati Denpasar \\ email: bagussuryatmaja@unmas.ac.id \\ ${ }^{3)}$ Universitas Mahasaras wati Denpasar \\ email: ekamartini@gmail.com
}

\begin{abstract}
ABSTRAK
Massive urban development and space utilization will ultimately trigger environmental problems. Issues related to the matter, such as reduced amount of green areas with less-controlled waste management, are important things need to be considered. In order to manage the problem, it is important to find a solution to arise hygiene behavior, as well as preserving green areas. Providing education for community, starting from early ages, is considered to be a valuable effort. Education can be provided by making a thematic park with $5 R$ (Reuse, Reduce, Recycle, Replace and Replant) principle, which can provide understanding through technology transfer model (TT) method, applying appropriate technology. In the future, the availability of thematic park will serve a novel medium for education training and community.
\end{abstract}

Keyword : Thematic park, education, $5 R$

\section{PENDAHULUAN}

\section{Latar Belakang}

Pembangunan selalu memberikan perubahan terhadap kondisi lingkungan. Kerusakan lingkungan sebagai dampak turunan dari pola pembangunan yang juga memiliki keterkaitan dengan peningkatan jumlah penduduk telah menjadiisu global yang meresahkan apabila tidak ditemukan solusi untuk mengatasinya.

Isu permasalahan lingkungan yang marak saat ini diantaranya adalah tergerusnya ruang terbuka hijau yang ada dan semakin tidak terkontrolnya peningkatan timbulan sampah baik itu sampah organic maupun anorganik.Timbulan sampah yang diakibatkan oleh aktifitas rumah tangga, industri, fasilitas kesehatan, maupun perkantoran dan semakin berkurangnya ruang terbuka hijau mengakibatkan terdegradasinya kondisi lingkungan secara umum.

Sebagai bagian dari suatu wilayah, keberadaan Ruang Terbuka Hijau (RTH) memiliki peranan penting dalam upaya menjaga kesehatan lingkungan dalam wilayah tersebut. Dengan berkurangnya jumlah luasan RTH akibat dari pola pembangunan yang terjadi saat ini, sangat penting untuk mencari solusi yang mampu memadukan kepentingan dalam menyehatkan lingkungan dari aspek upaya peningkatan keberadaan RTH dan penurunan aspek negatif timbulan sampah. 
Upaya ini dapat dimulai dengan memberikan pendidikan atau pengetahuan kepada masyarakat tidak hanya kepada kalangan dengan usia dewasa akan tetapi dimulai dari usia dini. Memberikan pemahaman dengan metode yang tepat kepada masyarakat diharapkan dapat merubah pola pandangan masyarakat terhadap keberadaan RTH dan pengelolaan sampah. Sementara ini masyarakat mulai melakukan pengelolaan terhadap keberadaan sampah dengan cara melakukan pemilahan dan beberapa diantaranya telah mencoba melakukan pengolahan kembali sehingga sampah dapat menjadi benda yang menguntungkan dari segi finansial sekaligus mengurangi dampak negatifnya terhadap lingkungan. Akan tetapi tidak banyak yang melakukan pengelolaan sampah dengan mengaitkannya terhadap keberadaan RTH. Sejatinya RTH tidak hanya dapat dilakukan secara horizontal tetapi juga dapat dilakukan secara vertical khususnya pada bidang-bidang ruang dengan lingkup yang kecil.

Dengan tujuan itulah perlu dilakukan suatu inovasi dalam penciptaan solusi mengenai permasalahan sampah dan RTH yang dapat dilakukan dengan pembuatan taman tematik. Taman tematik secara umum dapat dijelaskan sebagai taman dengan konsep khusus yang tidak hanya mampu memberikan citra visual yang menarik tetapi juga dapat memberikan nilai lebih sesuai dengan konsep yang dipilih.
Terkait dengan kondisi yang telah dijelaskan sebelumnya mengenai fenomena timbulan sampah dan menurunnya keberadaan RTH maka konsep taman tematik yang sesuai dengan situasi tersebut adalah taman edukasi 5R (Reuse, Reduce, Recycle, Replace dan Replant). Keberadaan taman tematik ini akan berfungsi sebagai media pendidikan, pelatihan dan juga lokasi keterlibatan masyarakat secara langsung dalam upaya peningkatan kondisi kesehatan lingkungan.

\section{Tujuan}

Keberadaan taman tematik edukasi $5 \mathrm{R}$ diharapkan mampu meningkatkan pemahaman masyarakat sejak usia dini hingga dewasa dalam pengelolaan sampah dan pentingnya ketersediaan RTH pada suatu wilayah untuk keberlangsungan lingkungan yang sehat.

\section{KAJIAN LITERATUR}

\section{Terminologi Taman Tematik}

\section{Taman}

Taman secara umum dapat dijelaskan sebagai sebidang lahan berpagar yang digunakan untuk mendapatkan kesenangan, kegembiraan dan kenyamanan (Laurie, 1990). Sedangkan menurut Nazzaruddin dalam Ilmiajayanti dan dewi menyatakan taman dijelaskan sebagai sebidang lahan terbuka dengan luasan tertentu dimana di dalamnya terdapat pepohonan, perdu, semak dan rerumputan yang bias dikombinasikan dengan kreasi dari bahan lainnya. Secara umum taman dapat dibagi menjadi dua, yaitu :

a) Taman Publik Aktif 
Taman yang memiliki fungsi sebagai tempat bermain dan olahraga, yang dilengkapi dengan elemen-elemen pendukung taman bermain dan lapangan olahraga seperti misalnya alun - alun.

b) Taman Publik Pasif

Taman ini hanya merupakan elemen estetis sehingga umumnya untuk menjaga keindahan tanaman di dalam taman akan dipasang pagar di sepanjang sisi luar taman.

\section{Taman Kota}

Taman kotaadalah suatu transisi atau sebagai penyekat hijau untuk memisahkan berbagai bentuk penggunaan lahan di dalam kota. Taman kota merupakan tempat tinggal manusia diluar ruangan untuk beraktivitas dan berinteraksi sosial untuk mendapatkan kesenangan, kegembiraan dan kenyamanan yang menunjukan pribadi suatu kota. Taman Kota memiliki berbagai fungsi diantaranya adalah (1) fungsi kesehatan, (2) fungsi keindahan, (3) fungsi peneduh, (4) fungsi pelestari ekosistem. (Halimatussadyah, 2014)

\section{Taman Tematik}

Taman Tematik merupakan bagian dari taman kota dimana istilah tematik dapat dijelaskan sebagai suatu program yang dapat digunakan untuk merevitalisasi taman - taman kota, seperti memperbaiki elemen - elemen taman, memperbanyak fasilitas untuk menunjang kegiatan - kegiatan masyarakat ataupun membuat suatu taman baru dengan memberikan tema pada taman
tersebut.Taman tematik adalah taman yang memiliki fungsi yang hampir sama dengan selayaknya taman-taman kota lain, namun yang membedakan adalah konsepdari tiap taman tersebut.

\section{Sampah}

Sampah merupakan salah satu problematika yang sangat lekat dengan kehidupan manusia. Hal tersebut dikarenakan hampir setiap aktivitas manusia akan menghasilkan sampah. Misalnya sampah rumah tangga, sampah kegiatan industry, sampah fasilitas kesehatan sampah perkantoran dan lain sebagainya. Sampah yang menumpuk dan tidak tertangani dengan baik pada akhirnya akan menimbulkan berbagai permasalahan, seperti misalnya pencemaran lingkungan khususnya terhadap kondisi air, udara dan tanah. Solusi permasalahan sampah hingga saat ini adalah dengan melakukan system 3R(reduce, reuse, recycle) yang saat ini sudah berkembang menjadi 5R (reduce, reuse, recycle, replace danreplant).

1. Reduce

reduce diartikan dengan mengurangi volume sampah. Kegiatan mengurangi pemakaian suatu barang atau pola perilaku yang dapat terhadap menurunnya produksi sampah. Contohnya adalah dengan mengurangi penggunaan barangbarang yang tidak bisa didaur ulang.

2. Reuse

Reuse diartikan dengan menggunakan kembali material atau bahan yang masih layak digunakan. Contohnya adalah 
penggunaan pipa atau minuman bekas sebagai tempat untuk tanaman hias.

3. Recycle

Kegiatan mengolah kembali sampah agar dapat digunakan kembali. Contohnya adalah mengolah kembali sampah organic sehingga dapat dijadikan pupuk organic atau MOL, juga mengolah kembali sampah anorganik menjadi barang kerajinan ataupun barang lain yang memiliki manfaat.

4. Replace

Kegiatan mengganti pemakaian suatu barang dengan barang alternatif yang sifatnya lebih ramah lingkungan.Contohnya yaitu penggunaan pupuk dari bahan olahan sampah organik.

5. Replant

Replant diartikan sebagai kegiatan penanaman kembali. Contohnya adalah dengan penanaman tanaman Toga yang juga memiliki manfaat bagi kehidupan rumah tangga.

\section{Desain Taman Tematik}

Desain taman tematik disesuaikan dengan konsep yang telah dipilih. Konsep - konsep tersebut biasanya unik dan bukan merupakan hal yang biasa dilihat oleh masyarakat. Taman tematik saat ini banyak dapat dilihat di Kota Bandung. Konsep taman yang ada sangat unik dan menarik, seperti misalnya taman fotografi, taman jomblo, taman superhero hingga pet park (taman binatang peliharaan). Tidak hanya unik, taman - taman tersebut memang memiliki fungsi sesuai dengan namanya. Seperti misalnya taman fotografi dibuat sebagai suatu wadah untuk pecinta dan penggiat fotografi dimana pada taman ini disediakan lokasi pengambilan foto dan tempat untuk memamerkan hasil foto. Sama halnya pada taman superhero yang memberikan tampilan nyata dari suatu imajinasi akibat kecintaan seseorang terhadap tokoh fantasi, juga pet park yang diciptakan untuk komunitas penyayang binatang.

Dalam penciptaan disain taman tematik, harus tetap memperhatikan berbagai aspek, diantaranya adalah aspek teknis yang terkait dengan pola ruang, aspek finansial dan aspek lingkungan. Aspek teknis adalah aspek yang memperhatikan bagaimana pola ruang taman yang juga terhubung dengan keberadaan hardscape dan softscape. Aspek finansial memperhatikan bagaimana keberadaan taman tersebut juga dapat memberikan keuntungan terhadap kondisi masyarakat sekitar. Aspek lingkungan memperhatikan benefit atau keuntungan yang mampu diberikan oleh keberadaan taman terhadap peningkatan kualitas lingkungan.

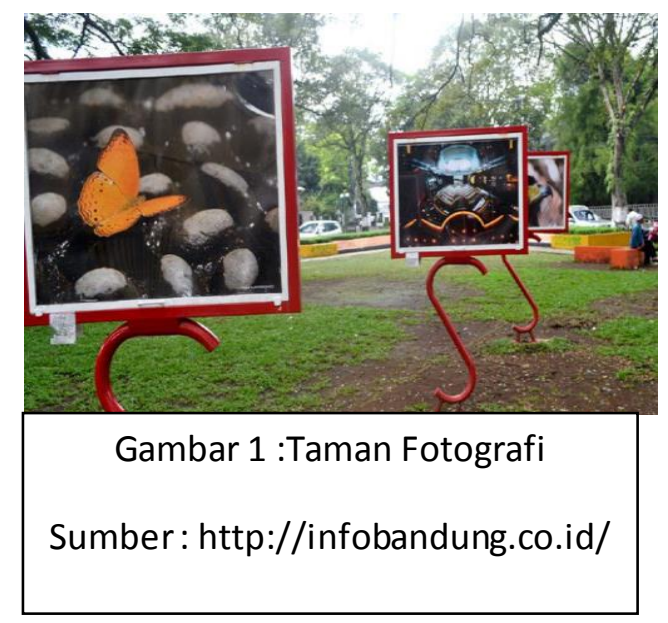



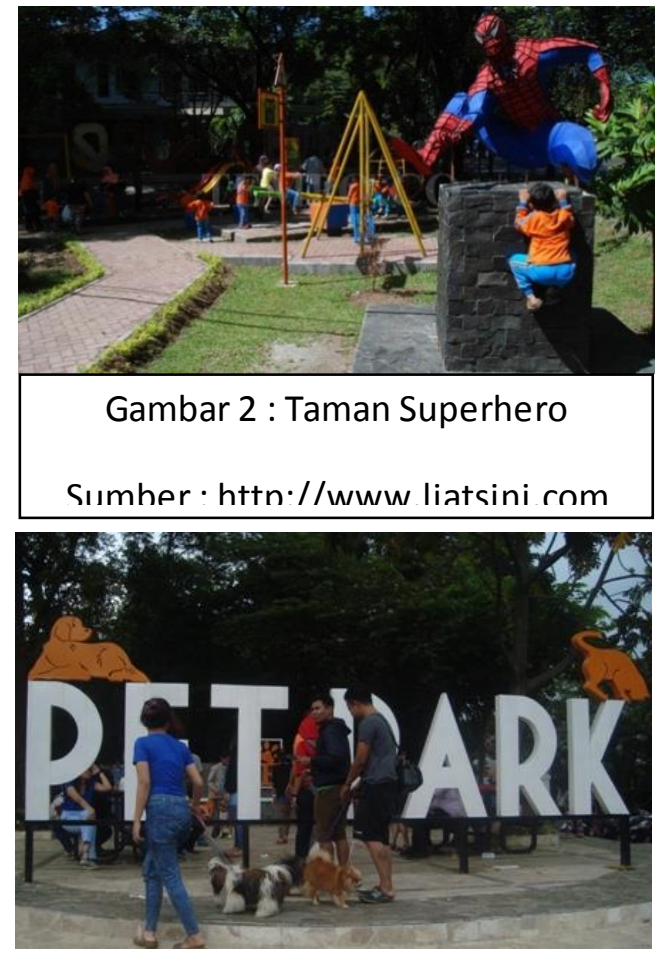

Gambar 3 : Pet Park

Sumber : http://www.liatsini.com

\section{METODELOGI}

\section{Pendekatan Pemberdayaan}

Indentifikasi masalah menggunakan

model partisipatory rural apprasial (PRA).Yang dimaksud model ini adalah dalam melaksanakan identifikasi masalah setiap program baik program SDM, SDA, Sarana dan Prasarana, juga dalam perumusan program dan pendanaan dilakukan secara terarah dengan berpihak dan melibatkan masyarakat. Dengan demikian dalam merumuskan masalah, mengatasi masalah, penentuan proses dan kreteria masalah harus mengikutsertakan bahkan ditentukan oleh masyarakat atau kelompok sasaran.

Penggunaan model pendekatan di atas diharapkan akan 1) dikenalnya masalah secara tepat atau efektif sesuai dengan persepsi, kehendak, dan ukuran/ kemampuan serta kebutuhan mereka, 2) tumbuhnya kekuatan (empowering) masyarakat atau kelompok sasaran dalam pengalaman merancang, melaksanakan, mengelola dan mempertanggungjawabkan upaya peningkatan/ pertumbuhan diri dan ekonominya, dan 3) efektifitas dan efisiensi penggunaan sumber daya masyarakat atau kelompok sasaran.

Rencana program aksi sebelum disosialisasikan kepada masyarakat atau kelompok sasaran, terlebih dahulu dikonsultasikan dengan Bappeda, Camat, dan Kepala Desa untuk kemudian memperoleh tanggapan / umpan balik / masukkan dari masyarakat atau kelompok sasaran yang akan digunakan sebagai bahan revisi dari rancangan program aksi.

Perencanaan program dengan cara di atas dapat mengembangkan potensi, inisiatif, dan daya kreasi (inducement), juga dapat mempengaruhi, mengarahkan, dan mempengaruhi pengendalian perubahan sosial, ekonomi, dan budaya pada kurun waktu tertentu.

\section{Pelaksanaan Pemberdayaan}

Pelaksanaan program dengan model enthrepreneurship capasity building (ECB). model Tecnology Transfer (TT), menerapkan Teknologi Tepat Guna (TTG) dan Demplot. Model ECB terkait erat dengan kemampuan berwirausaha dari masyarakat, dengan model ini akan 1) memberikan wawasan, sikap, dan keterampilan usaha, 2) 
memberikan peluang, 3) memfasilitasi (modal pinjamaan dsb.), dan 4) memonitor dan mengevaluasi bagaimana perkembangan usahanya.

Model TT dilakukan agar masyarakat atau kelompok sasaran : 1) menguasai prinsipprinsip penerapan teknologi terutama yang berkaitan dengan proyek yang sedang/akan dilaksanakan, 2) kalau teknologinya dirasakan terlalu rumit untuk menyelesaikan masalah/kebutuhan, maka ketua proyek mempunyai kewajiban untuk menyederhanakan melalui penerapan TTG, 3) memproduk yang bersifat mereplikasi atau modifikasi dengan alat sederhana atau melalui percontohan atau denplot yang dapat menyelesaikan masalah atau kebutuhan.

\section{SAMPAH MENJADI BERKAH}

\section{Taman Tematik Edukasi 5R}

Tema yang digunakan adalah Taman Edukasi Reduce, Reuse, Recycle, Replacedan Replant(5R). Tema ini digunakan dengan tujuan agar sampah sampah yang ada dapat diolah dan dimanfaatkan menjadi nilai ekonomi. Selain itu diharapkan dari pengolahan sampah ini hasil olahan akan menjadi ramah lingkungan. Melihat kondisi yang ada saat ini, permasalahan sampah yang semakin meningkat akibat turunan dari pembangunan dan pertumbuhan penduduk, mengharuskan adanya solusi untuk mengurangi dampak yang ditimbulkan. Pengolahan sampah organik maupun anorganik menjadi sangat penting karena jika sampah hanya dibuang dan berakhir di
Tempat Pembuangan Akhir (TPA), selain tidak memiliki nilai ekonomis juga dapat menimbulkan masalah baru dikemudian hari khususnya di daerah sekitar TPA.

\section{Proses Pengelolaan Limbah Organik Pentingnya pemupukan adalah} menyediakan unsur hara yang diperlukan tanaman untuk dapat tumbuh dan berproduksi secara optimal. Jenis pupuk berdasarkan bahan penyusunnya adalah pupuk kimia, pupuk organik dan pupuk hayati. Penggunaan pupuk kimia dalam budidaya tanaman sangat diminati petani dalam usaha meningkatkan produktivitas tanaman karena pupuk kimia dapat menyediakan unsurhara yang diperlukan tanaman secara cepat dan dalam jumlah yang tidak banyak. Akan tetapi, penggunaan pupuk kimia secara secara terus menerus tanpa diimbangi dengan pupuk organik dapat menyebabkan kadar bahan organik tanah menurun, struktur tanah rusak, dan mengakibatkan pencemaran lingkungan, dan jika hal ini terus berlanjut akan menurunkan kualitas tanah dan kesehatan lingkungan. Oleh karena itu, selain menggunakan pupuk kimia, sebaiknya petani juga menggunakan pupuk organik untuk meningkatkan atau mempertahankan kesuburan tanah.

Pupuk organik dapat dibagi menjadi 2 (dua) berdasarkan bentuknya yaitu pupuk organik padat dan pupuk organik cair. Salah satu jenis pupuk organik cair adalah yang umumnya dikenal sebagai Mikro Organisme Lokal (MOL) yang merupakan larutan hasil 
fermentasi. Bahan dasar MOL berasal dari berbagai sumber yang mengandung unsur hara mikro, makro, bakteri perombak bahan organik, perangsang pertumbuhan dan agen pengendali hama/penyakit tanaman. Oleh karena itu, MOL dapat dimanfaatkan sebagai (a) Pupuk organik cair, (b) Decomposer atau biang pembuatan kompos, (c) Pestisida nabati. Proses pembuatan MOL adalah sebagai berikut:

1. Limbah buah-buahan atau sayur-sayuran dihaluskan. Bisa dengan cara ditumbuk atau diparut.

2. Masukkan ke dalam dalam tempat (drum)

3. Tambahkan air kelapa.

4. Tambahkan gula.

5. Semua bahan diaduk sampai tercampur merata.

6. Tutup drum dengan penutup. Beri lubang untuk aerasi. Lubang aerasi ini bisa menggunakan selang agar tidak dimasukki oleh lalat atau serangga lain.

7. Semua bahan kemudian difermentasi selama 2 (dua) minggu sebelum digunakan.

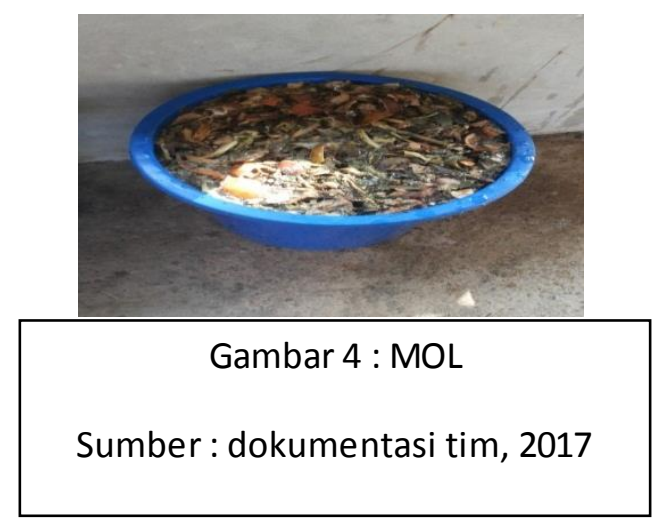

\section{Proses Pengelolaan Limbah Anorganik}

Limbah anorganik adalah limbah yang berasal bukan dari makhluk hidup. Limbah anorganik ini memerlukan waktu yang lama atau bahkan tidak dapat terdegradasi secara alami. Beberapa limbah anorganik diantaranya plastik, kaleng, dan bahan gelas atau beling. Salah satu pemanfaatan limbah anorganik adalah dengan cara proses daur ulang (recycle). Daur ulang merupakan upaya untuk mengolah barang atau benda yang sudah tidak dipakai agar dapat dipakai kembali. Beberapa limbah anorganik yang dapat dimanfaatkan melalui proses daur ulang, misalnya plastik, gelas, logam, dan kertas.

Limbah plastik biasanya digunakan sebagai pembungkus barang. Plastik juga digunakan sebagai perabotan rumah tangga seperti ember, piring, gelas, dan lain sebagainya. Keunggulan barang-barang yang terbuat dari plastik yaitu tidak berkarat dan tahan lama. Sehingga, upaya yang dapat dilakukan adalah memanfaatkan limbah plastik untuk didaur ulang menjadi barang lain dengan fungsi yang sama ataupun berbeda seperti ember plastik bekas dapat didaur ulang menjadi produk lain seperti tempat sampah, atau pot bunga. Plastik dari bekas makanan ringan atau sabun deterjen dapat didaur ulang menjadi kerajinan misalnya tas ataupun dompet. Botol bekas minuman bisa dimanfaatkan untuk membuat mainan anak-anak atau pot taman vertikal dan bentuk hiasan lainnya.Sampah kertas memiliki kecenderunganmudah hancur dan 
tidak berbahaya seperti sampah plastik, akan tetapi sampah kertas pasti menimbulkan masalah jika tidak ditanggulangi. Sampah dari kertas dapat didaur ulang untuk menjadi berbagai kerajinan yang bernilai dari segi ekonomi. Seperti misalnya frame foto, kotak tisu, serta hiasan dinding.

\section{Mendesain Taman Tematik}

Disain Taman Edukasi 5R, harus mampu mengaplikasikan setiap elemen yang terdapat dalam konsep taman. Disain dan fasilitas yang ada dalam taman harus mampu mewakili tema yang diusung. Konsep Edukasi 5R (Reduce, Reuse, Recycle, Replace dan Replant) harus benar-benar tertuang dan mampu memberikan pendidikan dan pemahaman yang tepat kepada masyarakat. Oleh sebab itu dalam mendesain taman tematik ini akan dibagi menjadi beberapa bagian yaitu :

1. Reduce

Konsep reduce yang diartikan dengan mengurangi volume sampah.Dalam taman ini dapat dibuat dalam bentuk papan informasi pemahaman mengenai bagaimana cara mengurangi volume sampah dengan cara perubahan pola perilaku dalam pemanfaatan atau penggunaan suatu barang sehingga dapat mengurangi produksi timbulan sampah.

2. Reuse

Konsep reuse yang diartikan dengan menggunakan kembali material atau bahan yang masih layak digunakan. Dalam disain taman ini diaplikasikan pada penggunaan pipa atau botol bekas sebagai tempat untuk tanaman hias baik vertical maupun horizontal.

\section{Recycledan Replace}

Konsep recycle diartikan dengan mengolah sampah agar dapat digunakan kembali. Pada taman ini diaplikasikan dengan pemanfaatan olahan sampah organic yang dijadikan pupuk organic atau MOL. Penggunaan pupuk organic juga senada dengan konsep replace yang diartikan untuk mengganti pemakaian barang alternatif yang lebih ramah lingkungan. Selain itu juga pada konsep ini dilakukan pengolahan sampah anorganik menjadi barang lain yang lebih bermanfaat.

4. Replant

Replant diartikan sebagai kegiatan penanaman kembali. Pada taman ini diaplikasikan dengan penanaman tanaman obat yang dapat dimanfaatkan oleh masyarakat.

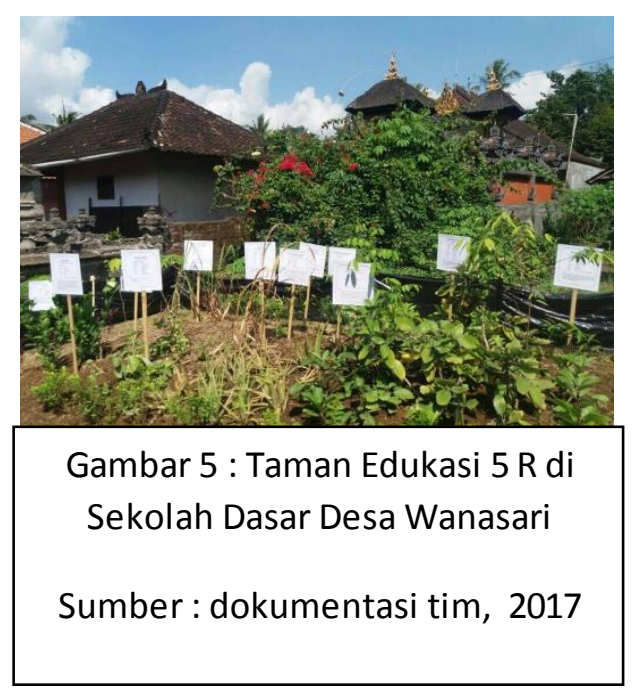




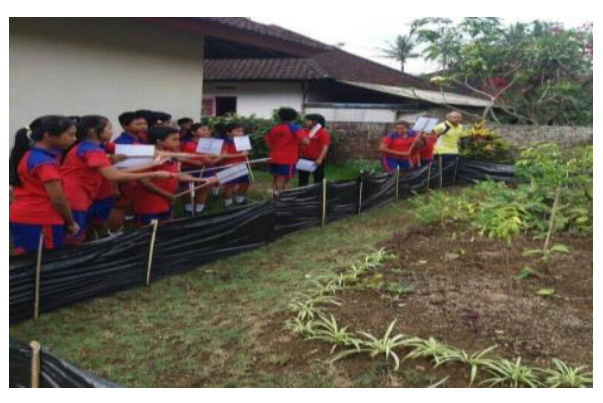

Gambar 6 : Siswa terlibat langsung dalam pengelolaan taman

Sumber : dokumentasi tim, 2017

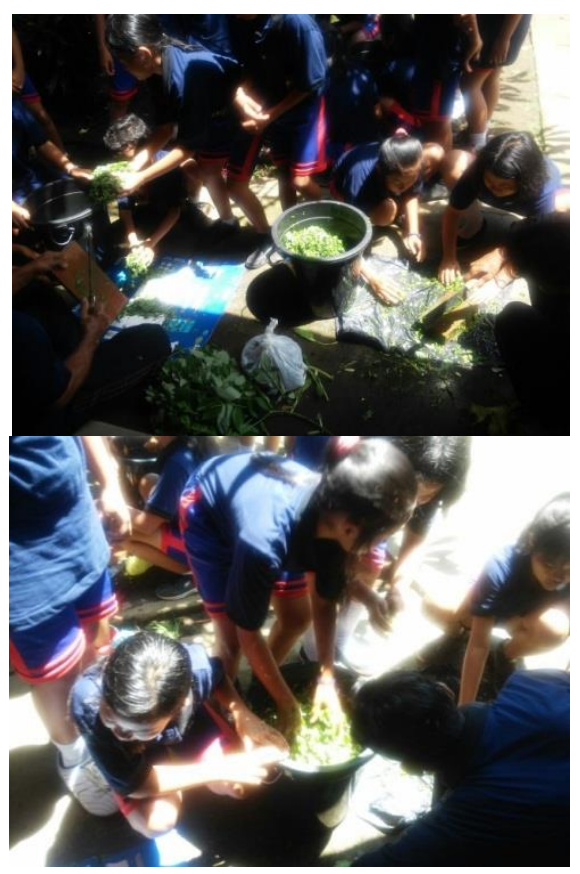

Gambar 8 : Pembuatan MOL oleh siswa Sekolah Dasar

Sumber: dokumentasi tim, 2017

\section{KEPUSTAKAAN}

Laurie, Michael., Onngodiputro, ArisK., 1990. Pengantar Kepada Arsitektur Pertamanan. Intermatra. Bandung

Ilmiajayanti, Freska., Dewi, Diah Intan Kusumo. 2015. Persepsi Pengguna Taman Tematik Kota Bandung Terhadap Aksesibilitas dan Pemanfaatannya. Jurnal Ruang. Volume I Nomor I. Semarang. Universitas Diponogoro

Halimatussadyah, Nur. 2014. Perancangan Situs Informasi Taman Tematik Kota Bandung. Tugas Akhir. Program Studi Desain Komunikasi Visual Fakultas Desain Universitas Komputer Indonesia. 